\title{
Outlet glacier dynamics and bathymetry at Upernavik Isstrøm and Upernavik Isfjord, North-West Greenland
}

\author{
Camilla S. Andresen, Kristian K. Kjeldsen, Benjamin Harden, Niels Nørgaard-Pedersen and \\ Kurt H. Kjær
}

During the past decades, the Greenland ice sheet has experienced a marked increase in mass loss resulting in an increased contribution to global sea-level rise. The three largest outlet glaciers in Greenland have increased their discharge, accelerated, thinned and retreated between 1996 and 2005. After 2005 most of them have slowed down again although not to previous levels. Geodetic observations suggest that rapid increase in mass loss from the north-western part of the ice sheet occurred during 2005-2010 (Kjeldsen et al. 2013).

Warming of the subsurface water masses off Greenland may have triggered the acceleration of outlet glaciers from the ice sheet (Straneo \& Heimbach 2013). The North Atlan- tic subpolar gyre, which transports water to South-East and West Greenland via the warm Irminger Current, warmed in the mid-1990s. Increased inflow of warm subpolar waters likely led to increased submarine melting of tidewater glaciers.

Climate, glacier configuration and ford bathymetry play fundamental roles for outlet glacier dynamics and thus knowledge of these parameters is warranted. In particular, the bathymetry of a ford gives important information about the exchange between fjord waters close to marine-terminating glaciers and the shelf and ocean. However, only sparse bathymetric data are available for the majority of fjords in Greenland. The International bathymetry chart for the Arc-

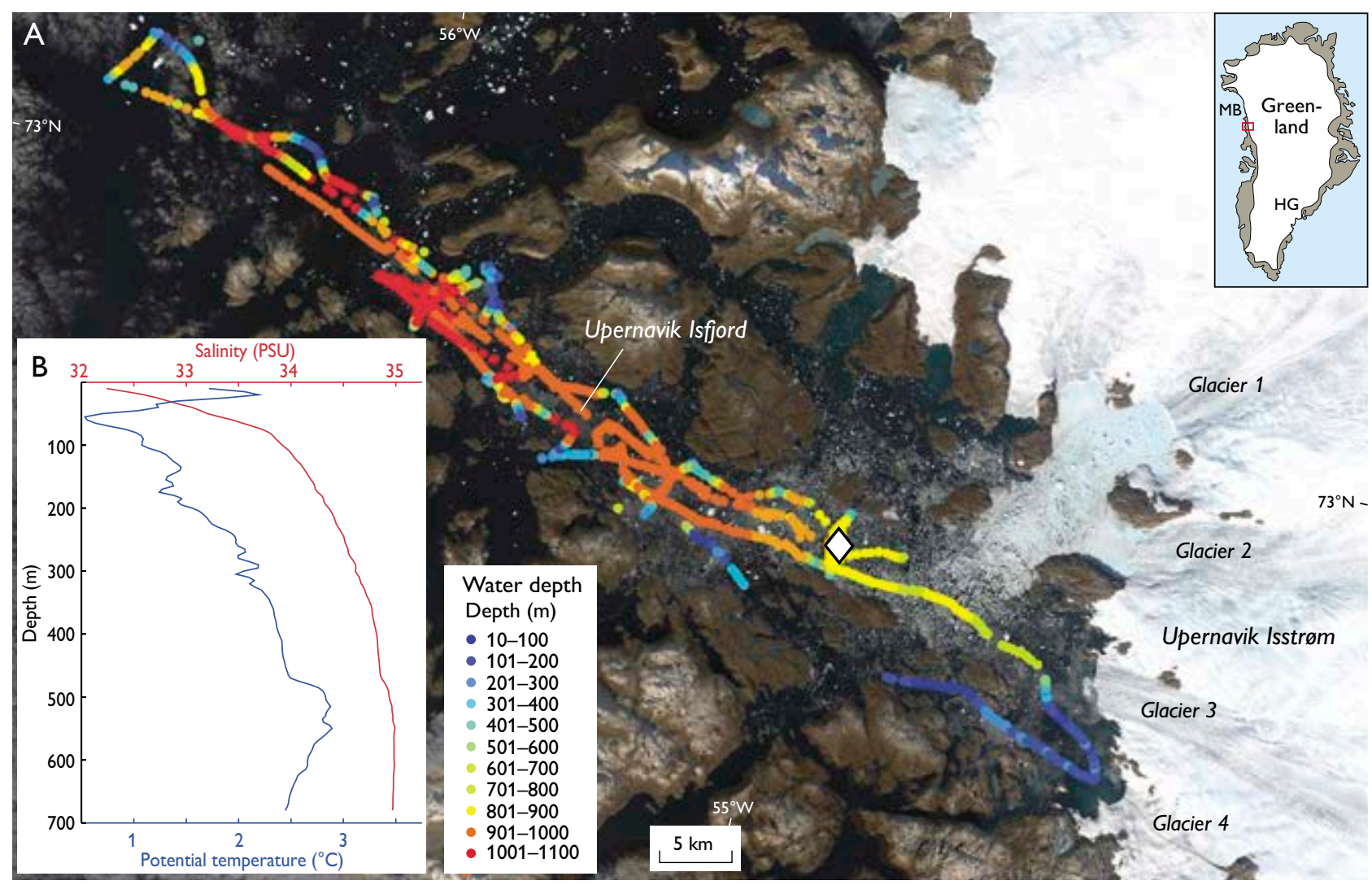

Fig. 1. A: Landsat 8 satellite image from August 2013 of the Upernavik Isfjord region with recorded water depths in the fjord. B: Temperature and salinity profiles at a mid-fjord site (white diamond). Data acquired in 2013 by oceanographers from Woods Hole Oceanographic Institution. MB: Melville Bugt. HG: Helheimgletscher. 


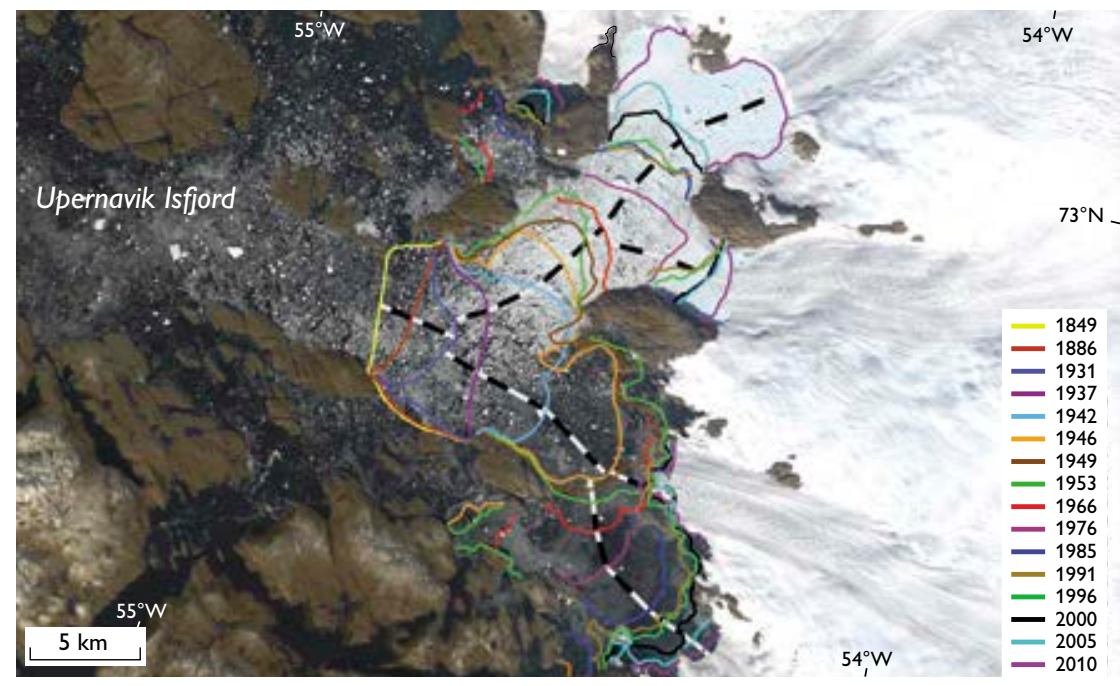

Fig. 2. Glacier frontal positions based on maps from historical expeditions, aerial photographs and satellite images (Weidick 1958; Khan et al. 2013), supplemented with a Corona satellite image from 1966 and a Landsat MSS image from 1976. The black and white lines show the tracks used for calculating single-point distances from the glacier margin.

tic Ocean (IBCAO) does not provide adequate data for the fjords and gives the impression that water depths in fjords are typically $<200 \mathrm{~m}$.

Here we present the first detailed bathymetric data from Upernavik Isfjord in North-West Greenland, which were obtained during a cruise led by the Geological Survey of Denmark and Greenland in August 2013. The purpose of the cruise was to retrieve sediment cores, collect hydrographic data and map the bathymetry of the fjord. In this paper, we also estimate retreat rates of the Upernavik Isstrøm since 1849 and evaluate them in the context of climate variability, glacier setting and fjord bathymetry.

\section{Upernavik Isstrøm and Upernavik Isfjord}

Upernavik Isstrøm consists of four main ice streams (glaciers 1-4, Fig. 1) that had a total mass loss of $53.5 \pm 12.8 \mathrm{Gt}$ during the period 2005-2010 (Khan et al. 2013). The four glaciers terminate in the $c .80 \mathrm{~km}$ long Upernavik Isfjord. Glaciers 1 and 2 are the most productive and the ford in front of these glaciers is packed with icebergs throughout the year. The bathymetric data (Fig. 1) show that most of the fjord is over $900 \mathrm{~m}$ deep, but water depths of 600-800 $\mathrm{m}$ are found near its head. Due to ice conditions, water depths could only be measured near glacier 4 where there is an area with water depths around $200 \mathrm{~m}$. Local fishermen report water depths of $600-700 \mathrm{~m}$ at a distance of $c .5-10 \mathrm{~km}$ from the fronts of glaciers 1-3. The survey ended slightly west of the ford mouth and there was no indication of a sill.

The hydrographic measurements show a c. $2^{\circ} \mathrm{C}$ warm, lowsalinity, $50 \mathrm{~m}$ thick surface layer. From 50 to $150 \mathrm{~m}$ cold polar water with a temperature of $0.5-1.5^{\circ} \mathrm{C}$ is found, and below this the water gradually warms from 1 to $3^{\circ} \mathrm{C}$ and becomes more saline, which shows that Atlantic water penetrates into the ford (Fig. 1). This also indicates that there is no shallow sill at the entrance to the fjord. Radar-based surveys suggest grounding line depths of $400-700 \mathrm{~m}$ for glaciers $1-3$ and $100 \mathrm{~m}$ for glacier 4 (Morlighem et al. 2014). This suggests that Atlantic water comes into contact with the fronts of glaciers 1-3, whereas the front of glacier 4 is in contact with polar water. This finding has implications for understanding the history of glacier retreat.

\section{Glacier retreat and climate change}

Frontal positions of Upernavik Isstrøm were compiled for the period from 1849 to 1953 by Weidick (1958; Fig. 2). Along with satellite images from 1966 and 1976 (this study) and more continuously since 1985 (Khan et al. 2013) these compilations provide a 150 years long record of glacier retreat since the Little Ice Age maximum position. Using the centre flow-line we estimate average annual retreat rates between glacier margin positions (Fig. 3C). From the Little Ice Age until c. 1931, the four glaciers were merged into one and retreated relatively slowly. The frontal retreat rate accelerated around 1931 and glaciers 1 and 2 and glaciers 3 and 4 started to split into two separate arms, and after 1946 glaciers 3 and 4 were decoupled from each other. The relatively high retreat rates lasted until the mid-1940s and were followed by lower retreat rates. Glaciers 1 and 2 decoupled from each other after 1966. Three subsequent episodes of increased retreat rates are seen: (1) between 1966 and 1985 (glaciers 1, 2 and 4), (2) late 1990s (glaciers 1, 2 and 4) and (3) 2005-2009 (all glaciers). During the latter period, the retreat rate of glacier 1 was exceptionally high. The temporal resolution of the data does not allow us to detect earlier similar rapid retreat events. In a recent study, data on frontal changes, thinning, and glacier velocity since 1985 were obtained from aerial photos and sat- 
ellite data and used to estimate dynamic mass loss (Khan $e t$ al. 2013). Glacier 4 experienced a marked mass loss episode, including $>100 \mathrm{~m}$ thinning, prior to 1991 . At the same time no marked changes were recorded for glaciers $1-3$. In contrast, between 2005 and 2009, glacier 1 sped up, retreated and thinned markedly, whereas glaciers $2-4$ were relatively stable. Kjær et al. (2012) documented two events of dynamic mass loss along the Melville Bugt coast but also noted a spatially variable pattern in the magnitude of these events. The extended retreat data presented here may indicate that the marked dynamic mass loss prior to 1991 of glacier 4 was preceded by an even more marked event between 1966 and 1985 affecting not only glacier 4 but also glaciers 1 and 2 .

Care should be taken in comparing magnitude and timing of retreat rates from merged and decoupled glaciers due to their different and temporally variable tributary sizes, glacier tongue widths and flow rates. Moreover, the estimated frontal positions are based on single points and may be subject to seasonal fluctuations and are thus only approximate. However, the timing of accelerated retreat rates in the different glaciers is fairly synchronous over inter-annual time scales. The onset of increased retreat rates in the 1930s of glaciers $1+2$ and $3+4$ as well as the increased retreat rates of glaciers $1+2$ around 1966 may have been initiated by their decoupling from the merged glacier and glaciers $1+2$ at this time. This would suggest that topographical constraints are important for retreat rates. Alternatively, a common climate change may have forced accelerated retreat and in this way caused the decoupling of glaciers.

The marked retreat episodes in 1931-1946 (of the merged glacier), in the late 1990s (glaciers 1, 2, 4) and in 2005-2009 (all glaciers, but most markedly glacier 1) occurred at times of marked warming near Upernavik and entire Greenland (Chylek et al. 2006). Marked retreat from 1930 to the 1940s has also been documented elsewhere in Greenland, specifically for Helheimgletscher in South-East Greenland (Andresen et al. 2012; Figs 1,3D) and has been ascribed to variations in the Atlantic multi-decadal oscillation (AMO). The AMO is a mode of variability with its main expression in sea-surface temperatures in the North Atlantic Ocean and influencing circum-Atlantic climate, including coastal Greenland. The AMO has a periodicity of $c .60$ years, and a positive AMO
Fig. 3. A: Atlantic multi-decadal oscillation (AMO) index (Schlesinger \& Ramankutty 1994). B: Annual average air temperature for Upernavik (data from the Danish Meteorological Institute). C: Calculated changes in rate $\left(\mathrm{m} \mathrm{yr}^{-1}\right)$. Negative values and colour-filled boxes: glacier retreat. Positive values and white boxes: glacier advance. Episodes characterised by increased retreat rates by Upernavik are highlighted with yellow boxes. D: Marine sediment-based proxy data from South-East Greenland. Relative variability in calving from Helheimgletscher based on sand fluxes (Andresen et al. 2012) and shelf sea-surface temperatures based on analyses of core ER07 from Sermilik fjord (Andresen $e t$ al. 2013). Yellow boxes highlight warm episodes with increased dynamic mass loss in South-East Greenland.

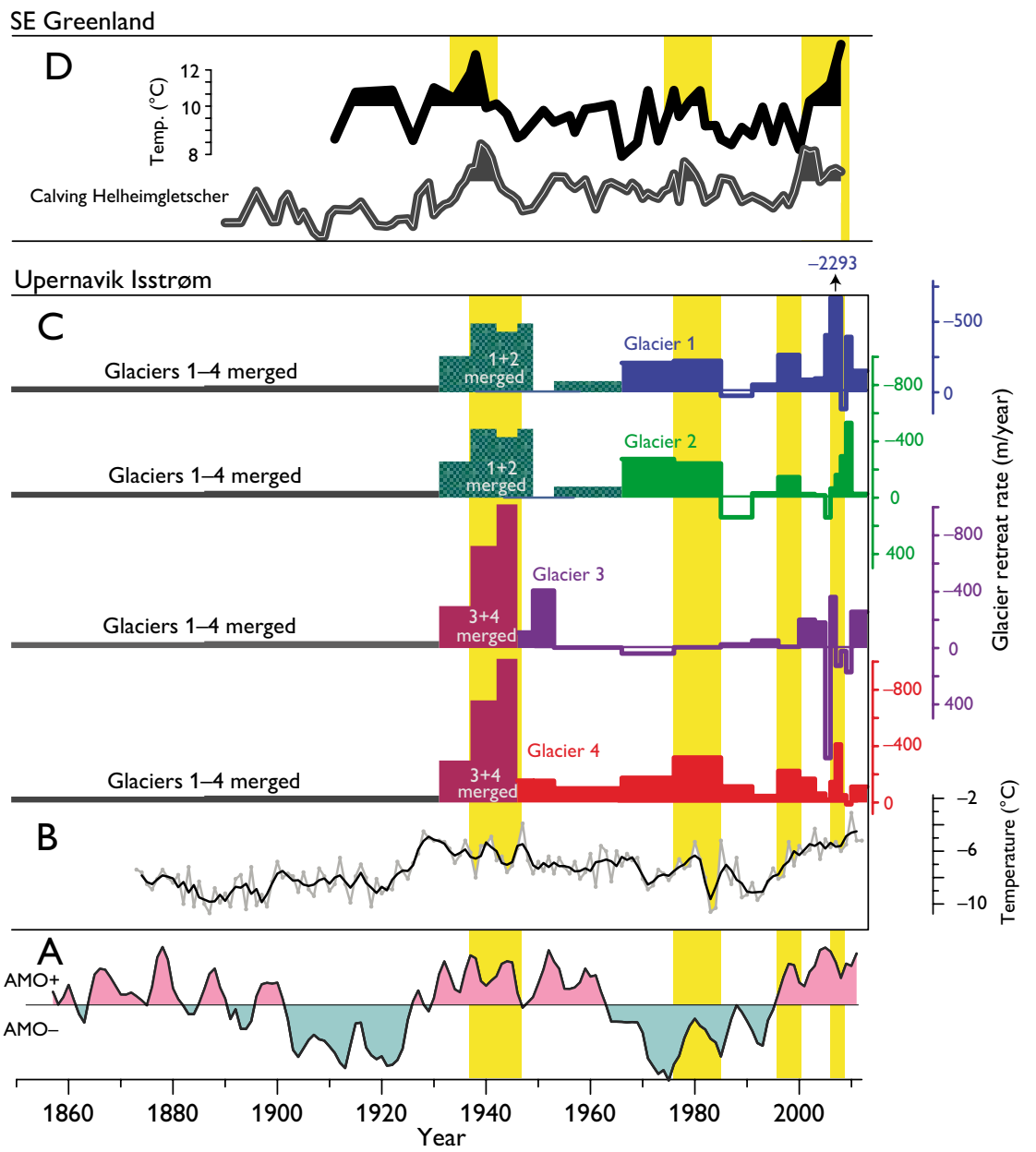


index is linked with higher sea-surface temperatures. The accelerated retreat episodes of Upernavik Isstrøm from 1930 to the 1940s, late 1990s and 2005-2009 could be associated with warming of subsurface waters during periods with positive AMO indexes (Fig. 3). However, since air temperatures co-vary with the AMO index on multi-decadal timescales (Figs 3A, B) it is not possible to differentiate directly between influence from increased air versus water temperatures on mechanisms that could lead to retreat of the glacier margin.

As noted the increased retreat rates of glaciers 1 and 2 between 1966 and 1985 may have been triggered by changed topographical constraints such as loss of pinning points as the combined glacier front widened considerably (Figs 2, 3C). However, due to the synchronous, high retreat rates of glacier 4 within its own tributary, as well as continued high retreat rates long after decoupling of glaciers 1 and 2, we speculate that climate forcing is also involved. The increased retreat differs from the other retreat episodes because it occurred during a negative AMO index. However, even though average sea-surface temperatures in the source region of Atlantic waters were generally low between the early 1960 s and the mid-1990s and annual air temperatures in Upernavik decreased slightly, air temperatures increased between the early 1970s and 1980. Interestingly, sediment-based proxy glacier and ocean data document a marked warming of Atlantic waters in South-East Greenland at this time along with a marked increase in calving from Helheimgletscher (Fig. 3D). The concurrency between this climate warming and glacier instability in South-East Greenland supports the theory that the increased retreat rates of glaciers 1,2 and 4 between 1976 and 1985 were forced by climate warming.

The front of glacier 4 has been located in a $200 \mathrm{~m}$ shallow area since the 1950s (Fig. 1) and the front of this glacier is not in direct contact with the deeper warm subsurface layer in the fjord. Although warming or increased thickness of the Atlantic water layer may increase the temperature of the polar water layer, we suggest that the accelerated retreat rates of glacier 4, including the 1985-1991 episode of marked thinning (Khan et al. 2013), may be linked with increased air temperatures. It has been suggested that meltwater percolating down the glacier being released as subglacial discharge may have a considerable influence on the submarine melt rates and thus glacier stabilisation.

We emphasise that the retreat record is not fully representative of glacier changes. Not only are the determined frontal positions rather sporadic and do not represent a continuous record of change, but in addition we need to assess thinning and flow-rate changes to obtain a more comprehensive picture of glacier changes since the Little Ice Age. One way to overcome this will be to analyse sediment cores to obtain a continuous proxy record of calving variability. This will add information on dynamic changes and can subsequently be linked to digital elevation models and mass-balance modelling to estimate mass loss. Our results also show that bathymetric conditions may partly explain asynchronous glacier responses to climatic warming. It is therefore important to incorporate bathymetric data when trying to understand and predict outlet-glacier behaviour. Hopefully future campaigns to collect and pool bathymetric data will provide improved bathymetric maps of the Greenland fjords.

\section{Acknowledgements}

The 'Upernavik Glacier Project' is funded by Geocenter Danmark. We thank Arctic Station on Disko for the use of the vessel Porsild and Hans Karl Petersen from Upernavik who was pilot during the survey of glacier 4 and provided water-depth information by glaciers $1-3$.

\section{References}

Andresen, C.S. et al. 2012: Rapid response of Helheim Glacier in Greenland to climate variability over the past century. Nature Geoscience $\mathbf{5}$, $37-41$.

Andresen, C.S., Sicre, M.-A., Straneo, F., Sutherland, D.A., Schmith, T., Ribergaard, M.H., Kuijpers, A. \& Lloyd, J.M. 2013: A 100-year record of alkenone-derived SST changes by Southeast Greenland. Continental Shelf Research 71, 45-51.

Chylek, P., Dubey, M.K. \& Lesins, G. 2006: Greenland warming of 19201930 and 1995-2005. Geophysical Research Letters 33, L11707.

Khan, S.A., et al. 2013: Recurring dynamically induced thinning during 1985 to 2010 on Upernavik Isstrøm, West Greenland. Journal of Geophysical Research: Earth Surface 118, 111-121.

Kjær, K.H. et al. 2012: Aerial photographs reveal late-20th-century dynamic ice loss in northwestern Greenland. Science 337, 569-573.

Kjeldsen, K.K., et al. 2013: Improved ice loss estimate of the northwestern Greenland ice sheet. Journal of Geophysical Research: Solid Earth 118, 698-708.

Morlighem, M., Rignot, E., Mouginot, J., Seroussi, H.\& Larour, E. 2014: Deeply incised submarine glacial valleys beneath the Greenland Ice Sheet. Nature Geoscience 7, 418-422.

Schlesinger, M.E. \& Ramankutty, N. 1994: An oscillation in the global climate system of period 65-70 years. Nature 367, 723-726.

Straneo, F. \& Heimbach, P. 2013: North Atlantic warming and the retreat of Greenland's outlet glaciers. Nature 504, 36-43.

Weidick, A. 1958: Frontal variations of Upernaviks Isstrøm in the last 100 years. Meddelelser fra Dansk Geologisk Forening 14, 52-60.

\footnotetext{
Authors' addresses

C.S.A. \& N.N.P., Geological Survey of Denmark and Greenland, Øster Voldgade 10, DK-1350 Copenhagen K, Denmark. E-mail: csa@geus.dk K.K.K. \& K.H.K., Natural History Museum of Denmark, University of Copenhagen, Øster Voldgade 5-7, DK-1350 Copenhagen K, Denmark. B.H., Woods Hole Oceanographic Institution, Woods Hole, MA 02543, USA.
} 